\title{
The Comparative Photosynthetic Responses of Pinus caribaea var. caribaea and Pinus tropicalis, from Western Cuba
}

Yudel García-Quintana ${ }^{1}$ (D) 0000-0002-9107-9310

Yasiel Arteaga-Crespo ${ }^{1}$ (1) 0000-0002-9817-9883

María de Decker ${ }^{1}$ (1) 0000-0002-1579-3432

Sonia Vega-Rosete ${ }^{2}$ (1) 0000-0003-2020-0205

Gretel Geada-López ${ }^{3}$ (1) 0000-0002-8421-0624

\begin{abstract}
This study aimed to evaluate the photosynthetic responses of Pinus caribaea Morelet var. caribaea Barret \& Golfari and Pinus tropicalis Morelet in the ecological conditions of Pinar del Río, Cuba. Data were collected in March 2015 using an open system IRGA-porometer LI-6400. The response of both species was measured by increasing concentrations of carbon dioxide and photosynthetically active radiation. Results indicated that under the same environmental conditions, $P$. caribaea var. caribaea is more productive than $P$. tropicalis, since $P$. caribaea var. caribaea, showed higher values of net $\mathrm{CO}_{2}$ assimilation and reaching the $\mathrm{CO}_{2}$ compensation point at $77 \mu \mathrm{mol} \mathrm{mol}^{-1}$, against the $113 \mu \mathrm{mol} \mathrm{mol}^{-1}$ registered by $P$. tropicalis. The species $P$. caribaea var. caribaea reached light saturation at lower values than $P$. tropicalis, and showed greater efficiency for the carboxylation of Rubisco. The results indicated that both species perform $\mathrm{C}_{3}$ photosynthetic mechanism.
\end{abstract}

Keywords: $\mathrm{CO}_{2}$ compensation point, photosynthesis, Pinus, net assimilation rate, photosynthetic active radiation.

\section{INTRODUCTION AND OBJECTIVES}

Primary processes such as gas exchange and water relations primarily determine plant development (Taiz \& Zeiger, 2006), and therefore, studying the influence of the environment is important for understanding plant habitats and niches (Bertrand et al., 2017).

The evolution of ecology and eco-physiology as integrative sciences of the biology of organisms, and relationships with both its physical habitat and their co-inhabitants are experimental sciences that generate basic knowledge; therefore, they participate in the process of planning and forecasting production (Kimball et al., 2016). Ecological principles can generate new paradigms and deliver management recommendations for production systems, which are more suited to each particular habitat; besides, they are more environmentally friendly (Diaz, 2001).

These perspectives allow us to determine which attributes are large-scale eco-physiological parameters in order to ensure pertinent management and better planned use of forest resources, on the basis of scientifically sound and well-understood mechanisms of acclimation and adaptation of the plant development.

Physiological techniques have enabled incorporating information related to the functional features of the state of the plants (Pelegrín et al., 2005; Singh \& Nangoy, 2016). Gas exchange is one of the most frequently used ecophysiological variables (Koussoroplis et al., 2017; Vallejo et al., 2003). Thus, the assessment of this variable has become more complex and opened up a wide spectrum for the interpretation of the plants' response, ranging from purely

\footnotetext{
${ }^{1}$ Universidad Estatal Amazónica (UEA), Puyo, Ecuador

${ }^{2}$ Universidad de Alicante (UA), San Vicente del Raspeig, Alicante, España

${ }^{3}$ Universidad de Pinar del Río (UPR), Pinar del Río, Cuba
} 
morphological traits to addressing the function of a species (Vilagrosa et al., 2005).

Pine forests are relevant given their position, due to their physiognomic range, the diversity of their uses and a high economic and ecological value (Torngern et al., 2017). In Western Cuba, forests are composed only by two endemic pine species, of which little is known about their ecophysiology. Also, there is a lack of specific studies on the photosynthetic response to allow the understanding of the levels of productivity. Therefore, the study of the environmentspecies relationships in the ecological conditions of Pinar del Río deserves special attention. This research aimed to evaluate and compare the photosynthetic response of $P$. caribaea and $P$. tropicalis in the same ecological conditions.

\section{MATERIALS AND METHODS}

\subsection{Geographical location and sample selection}

The trial was conducted in an experimental area of the Pinar del Río Botanical Garden, located at $22^{\circ} 20^{\prime} 45^{\prime \prime} \mathrm{N}$, $84^{\circ} 00^{\prime} 40^{\prime \prime} \mathrm{W}$, at an altitude of 196 masl. The site has clayey soil, with little organic matter content, gravel, and has low natural fertility; annual rainfall of $1,600 \mathrm{~mm}$ and an average temperature of $24.2^{\circ} \mathrm{C}$ (Frías, 2013; García et al., 2013). We selected five P. caribaea var. caribaea and P. tropicalis, considering their health status, phenotype, development and exposure to light.

\subsection{Gas exchange measurements}

The gas exchange measurements were performed using the portable photosynthesis device called the IRGAporometer LI-6400 (Licor, Inc.; Lincoln, NE, USA). Specific measurements of the photosynthetically active radiation (PAR) were conducted in March 2015.

\subsection{Photosynthetic kinetics}

Photosynthetic kinetics was recorded with five replications in response to different PAR intensities and several levels of intracellular $\mathrm{CO}_{2}$ concentration (Ci) (Tezara et al., 2003; Tezara et al., 2014; Warren et al., 2011).

The kinetics in response to $\mathrm{Ci}$ was recorded between 11 a.m. and 1 p.m., maintaining the value of the incident radiation on the pine needles $\left(800 \mu \mathrm{mol} \mathrm{m}^{-2} \mathrm{~s}^{-1}\right)$. The fit of the curves (Equation 1) was performed using temperature $\left(32^{\circ} \mathrm{C}\right)$ of the chamber assimilation constant, and varying the levels of $\mathrm{CO}_{2} \mathrm{Ci}$ from 0 to $600 \mu \mathrm{mol} \mathrm{mol}^{-1}$, with relative humidity of $23 \pm 2 \%$ (Tezara et al., 1998).

$$
A=b+d \times e^{\left(K \times C_{i}\right)} \cdot(1)
$$

where b: $\mathrm{CO}_{2}$-saturated photosynthetic capacity; $\left(\mathrm{A}_{\text {sat }}\right)$ and $(b+d)=y \pm$ intercept (Tezara et al., 1998). Carboxylation efficiency (CE) was calculated from the initial slope of the curve.

The kinetics in response to the PAR was carried out from 1 p.m. to 3 p.m., maintaining the concentration of $\mathrm{CO}_{2}$ $\left(400 \mu \mathrm{mol} \mathrm{mol}^{-1}\right)$ and the temperature of the assimilation chamber $\left(32^{\circ} \mathrm{C}\right)$ constant, varying the humidity of $19 \pm 2 \%$, at PAR levels ranging from 0 to $2,000 \mu \mathrm{mol} \mathrm{m}^{-2} \mathrm{~s}^{-1}$, every 2.5 minutes for each PAR level.

Photosynthetic kinetics was recorded with five replications in response to different PAR intensities, and various levels of intracellular Ci, using ideas from Prado \& Moraes (1997) for fitting the curves.

For kinetics measures, the portable photosynthesis device LI-6400 (Licor, Inc.; Lincoln, NE, USA) was used, because it allows one to control the temperature of the assimilation chamber, the incident radiation on the pine needles using a programmable lamp (6400-02B LED Light source), and the $\mathrm{CO}_{2}$ concentration with a dosing attachment of this gas (6400-01 $\mathrm{CO}_{2}$ Mixer). It also allows one to fix the maximum acceptable variation coefficient for each recorded value; in this case such maximum was set at $2 \%$.

The averages and standard deviation were plotted using the data obtained on the kinetics of assimilation (A) in response to $\mathrm{Ci}$ and PAR from the five repetitions. Ci kinetics were determined in three physiological parameters: compensation point, $\mathrm{CO}_{2}$ saturation point, and the efficiency of the Rubisco enzyme (CE) were estimated based on the initial slope of the kinetics obtained (Farquhar \& Sharkey, 1982). On the PAR kinetics, the compensation points and light saturation were determined.

Stomatal conductance and perspiration were monitored for five days, throughout the day in both species, recording values at 8 a.m., 10 a.m., 12 p.m., 2 p.m. and 4 p.m., with IRGA-porometer.

Statistical significance of photosynthetic parameter was assessed through one-way of variance (ANOVA) at $p<0.05$, using the SPSS software ver. 22.0.

\section{RESULTS AND DISCUSSION}

\subsection{Kinetics and photosynthetic parameters}

The kinetics of assimilation (A) in P. caribaea and $P$. tropicalis were plotted against intercellular $\mathrm{C}_{\mathrm{i}}$ (Figure 1). Such kinetics revealed that with a constant $800 \mu \mathrm{mol} \mathrm{m}^{-2} \mathrm{~s}^{-1}$ PAR, the saturation point $(\Gamma)$ of photosynthesis occurred 
at $473 \mu \mathrm{mol} \mathrm{mol}{ }^{-1} \mathrm{C}_{\mathrm{i}}$ for $P$. caribaea var. caribaea, and at $417 \mu \mathrm{mol} \mathrm{mol}^{-1} \mathrm{CO}_{2}$ for $P$. tropicalis. Assimilation was higher

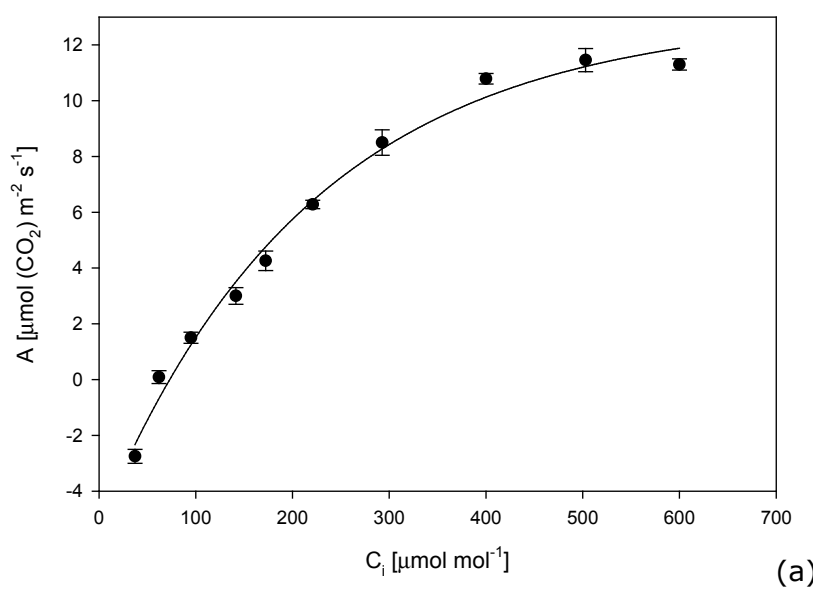

in P. caribaea var. caribaea with $11.39 \mu \mathrm{mol} \mathrm{mol}^{-1} \mathrm{CO}_{2} \mathrm{~m}^{-2}$ $\mathrm{s}^{-1}$, while in $P$. tropicalis it was $7.36 \mu \mathrm{mol} \mathrm{mol}{ }^{-1}$.

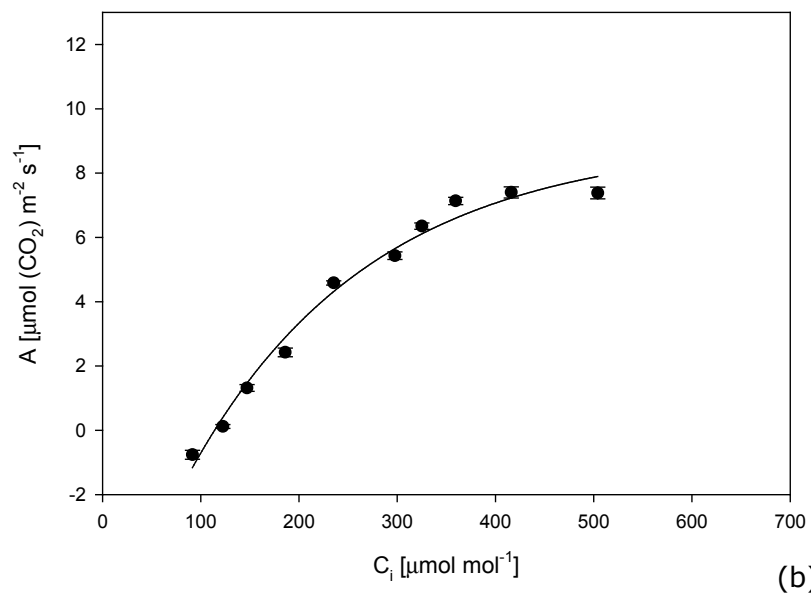

Figure 1. Curves of net photosynthetic rate (A) to intercellular $\mathrm{CO}_{2}$ concentration (Ci) of (a) P. caribaea var. caribaea and (b) P. tropicalis.

The PAR compensation point $(\Gamma)$, which represents the $\mathrm{CO}_{2}$ concentration, and photosynthesis equals respiration, was $77 \mu \mathrm{mol} \mathrm{mol}^{-1}$ for $P$. caribaea var. caribaea; and even higher in P. tropicalis, with values close to $113 \mu \mathrm{mol} \mathrm{mol}^{-1}$ (Figure 2). These values correspond to plants with $\mathrm{C}_{3}$ metabolism according Begon et al. (1988), and indicate that $P$. caribaea var. caribaea showed higher photosynthetic efficiency under the same ecological

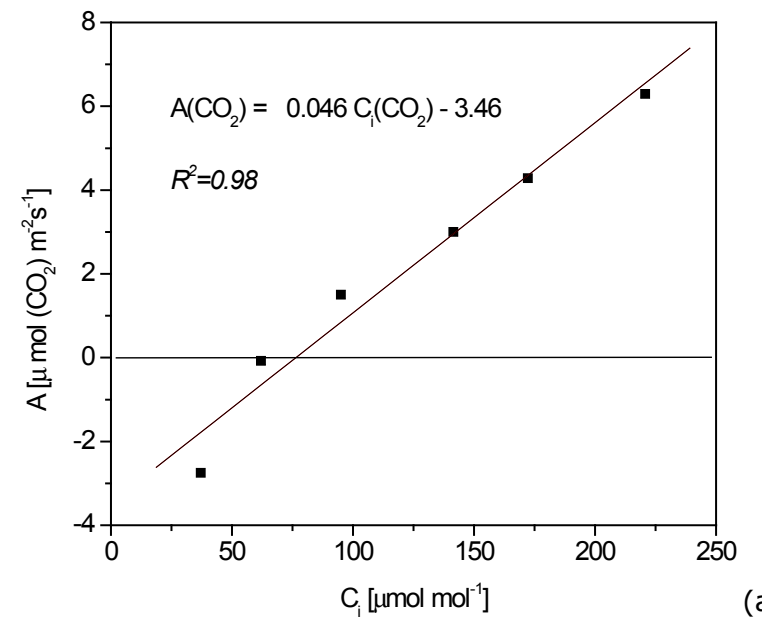

conditions for both species, such as soil nutrient content, light and water availability, and topography.

Carboxylation efficiency for both species (equivalent to the slope of the line drawn with the points recorded from 0 to $200 \mu \mathrm{mol}$ of $\mathrm{CO}_{2}$ per mole) was $0.046 \mu \mathrm{mol}$ per mole of $\mathrm{CO}_{2}$ air for P. caribaea var. caribaea, indicating that Rubisco is more efficient in the capture of $\mathrm{CO}_{2}$ in comparison to $P$. tropicalis which showed an efficiency of $0.038 \mu \mathrm{mol} \mathrm{mol}^{-1}$.

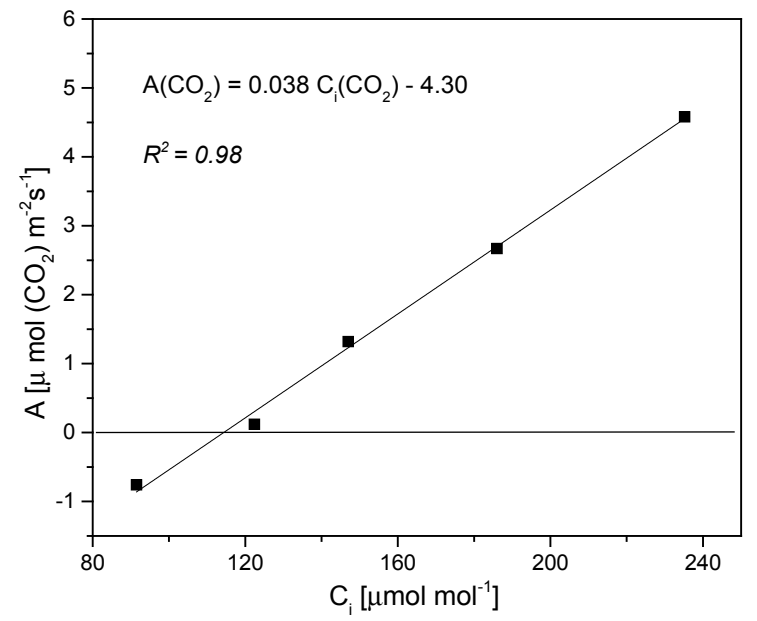

Figure 2. $\mathrm{CO}_{2}$ compensation point for (a) P. caribaea var. caribaea and (b) P. tropicalis.

In response to PAR, the kinetics of A depending on the light (PAR) is shown in Figure 3. In this case, a constant concentration of $\mathrm{CO}_{2}$ of $400 \mu \mathrm{mol} \mathrm{mol}^{-1}$, P. caribaea var. caribaea reached photo-saturation with $1,509 \mu \mathrm{mol} \mathrm{m}^{-2} \mathrm{~s}^{-1}$, with a rate of $\mathrm{A}$ of $\mathrm{CO}_{2}$ close to $6 \mu \mathrm{mol} \mathrm{m} \mathrm{m}^{-1}$. The light compensation point occurred at
$37 \mu \mathrm{mol} \mathrm{m}^{-2} \mathrm{~s}^{-1}$ with an A zero, since this is when photosynthesis matches respiration. Similar results were obtained by Ingwers et al. (2016) in a study of physiological attributes of three and four needle fascicles of Pinus taeda (loblolly pine), where they obtained an assimilation of $4 \mu \mathrm{mol} \mathrm{m} \mathrm{s}^{-2}$. 

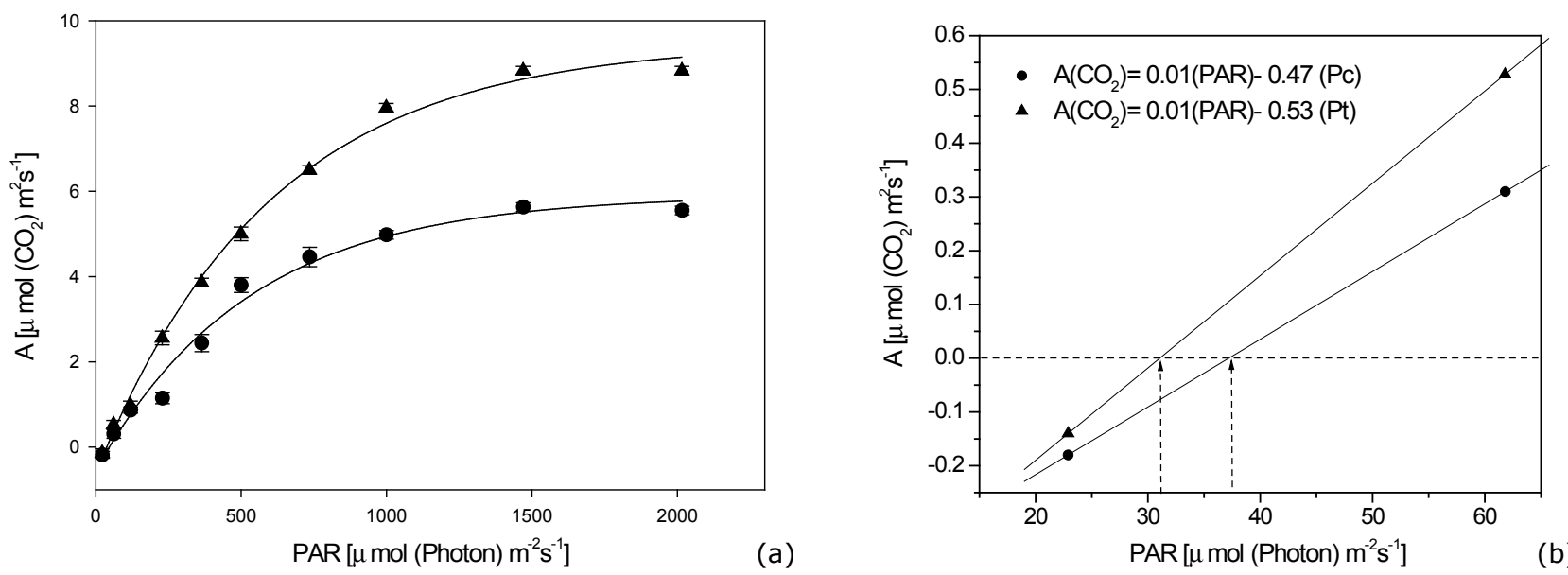

Figure 3. Curves of assimilation of $\mathrm{CO}_{2}(\mathrm{~A})$ to photosynthetically active radiation (PAR) of $P$. caribaea var. caribaea (Pc) and P. tropicalis (Pt) (a), and Light compensation point for P. caribaea var. caribaea and P. tropicalis (b).

In P. tropicalis, the light saturation reached $1,605 \mathrm{~m}^{-2} \mathrm{~s}^{-1}$, with a rate of an $\mathrm{A}$ of $\mathrm{CO}_{2}$ close to $9 \mu \mathrm{mol} \mathrm{m}{ }^{-2} \mathrm{~s}^{-1}$, and the light compensation point occurred at $31 \mu \mathrm{mol} \mathrm{m}^{-2} \mathrm{~s}^{-1}$. These results also indicate that $P$. caribaea var. caribaea under these ecological conditions photo-saturates at slightly lower values than P. tropicalis. García et al. (2013) gave requirements concerning light, in which $P$. tropicalis presents a more heliophilous character than $P$. caribaea var. caribaea. In the case of Pinus strobus, Fréchette et al. (2016) observed that, under different light conditions, it reached values of assimilation close to $9 \mathrm{CO}_{2} \mu \mathrm{mol} \mathrm{m}{ }^{-2} \mathrm{~s}^{-1}$ and compensation point values between 20 and $45 \mu \mathrm{mol}$ $\mathrm{m}^{-2} \mathrm{~s}^{-1}$. On the other hand, Busch et al. (2007) obtained values of assimilation lower than $3 \mathrm{CO}_{2} \mu \mathrm{mol} \mathrm{m}^{-2} \mathrm{~s}^{-1}$ for Pinus banksiana (Jack pine).

Table 1 shows the ANOVA analysis of the two variables of pine species: assimilation (A), saturation point $(\Gamma)$ and carboxylation efficiency (CE). The results indicated that they have significant (sig.) difference in the photosynthetic parameters $(\mathrm{p}<0.005)$.

Table 1. ANOVA for photosynthetic parameters.

\begin{tabular}{|c|c|c|c|c|c|c|}
\hline & & $\begin{array}{l}\text { Sum of } \\
\text { Squares }\end{array}$ & df & Mean Square & F-Value & Sig \\
\hline \multirow{3}{*}{$A\left(\mu \mathrm{mol} \mathrm{m} \mathrm{m}^{-2} \mathrm{~s}^{-1}\right)$} & Between groups & 19.279 & 1 & 19.279 & 804.862 & 0.000 \\
\hline & Within groups & 0.096 & 4 & 0.024 & & \\
\hline & Total & 19.375 & 5 & & & \\
\hline \multirow[b]{2}{*}{$\Gamma\left(\mu \mathrm{mol} \mathrm{mol}{ }^{-1}\right)$} & Between groups & 2560.343 & 1 & 2560.343 & 2680.001 & 0.000 \\
\hline & Within groups & 3.821 & 4 & 0.955 & & \\
\hline \multirow{3}{*}{$\mathrm{CE}\left(\mu \mathrm{mol} \mathrm{mol}{ }^{-1}\right)$} & Between groups & 0.000 & 1 & 0.000 & 96.000 & 0.001 \\
\hline & Within groups & 0.000 & 4 & 0.000 & & \\
\hline & Total & 0.000 & 5 & & & \\
\hline
\end{tabular}

A: assimilation; $\Gamma$ : saturation point; CE: carboxylation efficiency; df: degrees of freedom; Sig: statistical significance. 
The results above are in agreement with the behavior of the transpiration rates and stomatal conductance reached by both pine species (Figure 4). As observed, P. caribaea recorded values are higher than $P$. tropicalis. It is known that both stomatal conductance and transpiration are indicators of stomatal opening,

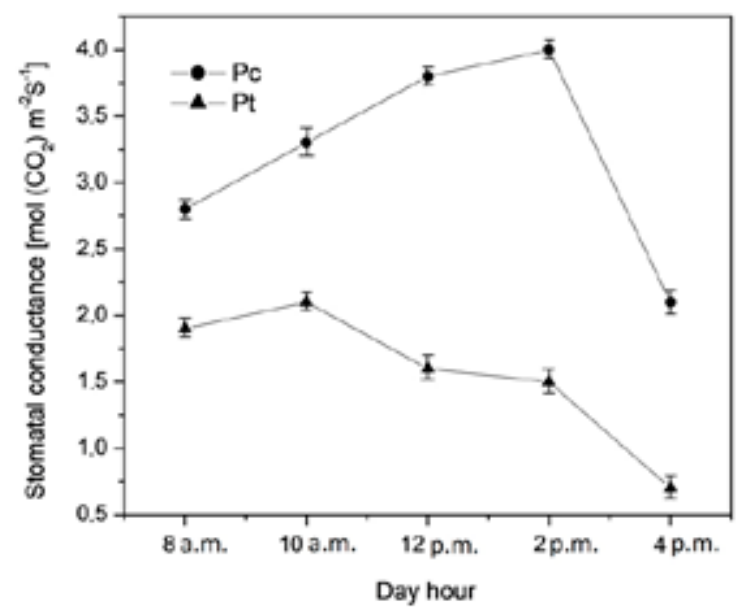

(a) which favors the entry of $\mathrm{CO}_{2}$ into the cellular interior and consequently manifests itself in greater photosynthetic activity (Anev et al., 2016; Azcón-Bieto \& Talón, 2008; García et al., 2014; Hogan et al., 1995). This indicates that $P$. caribaea reaches higher rates of $\mathrm{CO}_{2}$ fixation and is more productive.

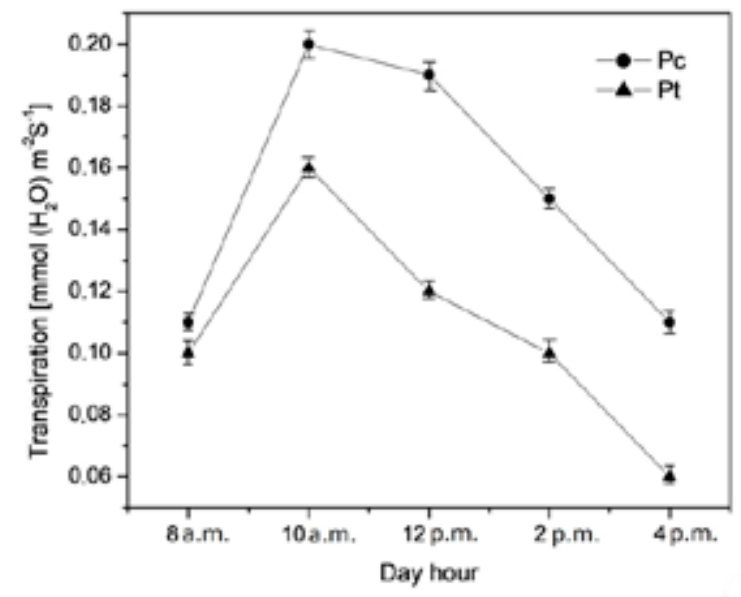

(b)

Figure 4. Measures of stomatal conductance for $P$. caribaea var. caribaea (Pc) and $P$. tropicalis (Pt) (a). Transpiration for $P$. caribaea var. caribaea $(\mathrm{Pc})$ and $P$. tropicalis $(\mathrm{Pt})(\mathrm{b})$.

Many studies based on experiments under greenhouse conditions reveal that changes in stomatal conductance were the main cause of decreased photosynthesis. Different studies (Flexas \& Medrano, 2002; Galmés et al., 2011; Saibo et al., 2009) led to the conclusion that a reduced rate of photosynthesis had a strong correlation with conductance as shown in potted grape wine plants. This strong relation led to the assumption that the down regulation of photosynthesis depends more on the availability of $\mathrm{CO}_{2}$ in the chloroplast than on leaf water content or water potential.

Riikonen et al. (2016) found that, for Picea abies and Pinus sylvestris, the assimilation values were lower than $4 \mu \mathrm{mol} \mathrm{m}^{-2} \mathrm{~s}^{-1}$ and stomatal conductance less than $0.10 \mathrm{~mol} \mathrm{~m}^{-2} \mathrm{~s}^{-1}$.

Conifers of western Cuba, although sharing the same habitat, respond in different ways to the ecological conditions of Pinar del Río. P. caribaea var. caribaea is more productive with higher values of $\mathrm{CO}_{2}$ assimilation, reaching its $\mathrm{CO}_{2}$ compensation point and light saturation at lower values than P. tropicalis and has greater efficiency at the carboxylation of Rubisco. These results can be attributed to the anatomical features of their needles and fundamentally to the difference in the number of stomata per unit area, where a greater amount has been reported for $P$. caribaea var. caribaea (García et al., 2013; Pérez del Valle et al., 2016). The species $P$. caribaea var. caribaea presents more needles per fascicle than $P$. tropicalis, which could explain its higher productivity. Ingwers et al. (2016) reported higher assimilation of $\mathrm{CO}_{2}$ when Pinus taeda presented four needles per fascicle.
This study shows that both species perform a $\mathrm{C}_{3}$ photosynthetic mechanism. The obtained results contribute to the scientific basis for the prudent and planned management of pine species, which will contribute to optimize forest production. The gas exchange processes under the controlled environmental conditions of Pinar del Río allow a better understanding of the differences between the species, which provides key information for the foresters who are dedicated to the establishment of mixed masses of $P$. caribaea species and P. tropicalis. This will allow decisions to independently establish these species in a way that optimizes their growth, survival, development and production.

\section{CONCLUSIONS}

The species $P$. caribaea var. caribaea presented greater photosynthetic efficiency than P. tropicalis in the same ecological conditions, expressed through measures of assimilation of $\mathrm{CO}_{2}$, light compensation point, stomatal conductance and transpiration. The differences found can be attributed to the anatomical characteristics of their needles and fundamentally to the difference in the number of stomata per unit area, which infers a more productive character. These results provide valuable information for the management of the two pine species that are established as a mixture in the western zone of Cuba. 


\section{ACKNOWLEDGEMENTS}

The authors thank the Universidad Estatal Amazónica for the financial support.

\section{SUBMISSION STATUS}

Received: 30 Mar. 2017

Accepted: 31 July 2018

Associate editor: João Latorraca

\section{CORRESPONDENCE TO Yudel García-Quintana}

Universidad Estatal Amazónica (UEA), Km. 2 1/2 vía Puyo a Tena (Paso Lateral), CP 032892-118, Puyo, Ecuador

e-mail: ygarcia@uea.edu.ec

\section{REFERENCES}

Anev S, Ivanova A, Tzvetkova N, Panayotov M, Yurukov S. Stomatal control on photosynthesis in drought-treated subalpine pine saplings. Genetics and Plant Physiology 2016; 6(1-2), 43-53.

Azcón-Bieto J, Talón M. Fundamentos de fisiología vegetal. Madrid: McGraw-Hill; 2008.

Begon M, Harper JL, Townsend CR. Ecología: individuos, poblaciones y comunidades. Barcelona: Omega; 1988.

Bertrand C, Devin S, Mouneyrac C, Giambérini L. Eco-physiological responses to salinity changes across the freshwater-marine continuum on two euryhaline bivalves: Corbicula fluminea and Scrobicularia plana. Ecological Indicators 2017; 74: 334-342. 10.1016/j.ecolind.2016.11.029

Busch F, Hüner NPA, Ensminger I. Increased air temperature during simulated autumn conditions does not increase photosynthetic carbon gain but affects the dissipation of excess energy in seedlings of the evergreen conifer jack pine. Plant Physiology 2007; 143: 12421251. 10.1104/pp.106.092312

Diaz M. Ecología experimental y ecofisiología: bases para el uso sostenible de los recursos naturales de las zonas áridas neo-tropicales. Interciencia 2001; 26: 472-478.

Farquhar GD, Sharkey TD. Stomatal conductance and photosynthesis. Annual Review of Plant Physiology 1982; 33: 317-345. 10.1146/ annurev.pp.33.060182.001533

Flexas J, Medrano H. Drought-inhibition of photosynthesis in C3 plants: stomatal and non-stomatal limitations revisited. Annals of Botany 2002; 89(2): 183-189. 10.1093/aob/mcf027

Fréchette E, Chang CYY, Ensminger I. Photoperiod and temperature constraints on the relationship between the photochemical reflectance index and the light use efficiency of photosynthesis in Pinus strobus. Tree Physiology 2016; 36: 311-324. 10.1093/treephys/tpv143

Frías TM, Pérez-Díaz N, Castillo-Martínez IC. Evaluación de plantas de Eucalyptus grandis Hill Ex Maiden a los 60 meses de plantadas obtenidas en contenedores con diferentes sustratos y riego de endurecimiento. Revista Cubana de Ciencias Forestales 2013; 1(1): 74-83.
Galmés J, Conesa MÀ, Ochogavía JM, Perdomo JA, Francis DM, Ribas-Carbó $\mathrm{M}$ et al. Physiological and morphological adaptations in relation to water use efficiency in Mediterranean accessions of Solanum lycopersicum. Plant, Cell \& Environment 2011; 34(2): 245. 10.1111/j.1365-3040.2010.02239.x

García JNG, Fischer G, Melgarejo LM. Relación entre la densidad estomática, la transpiración y las condiciones ambientales en Feijoa (Acca sellowiana [o. Berg] Burret). Revista UDCA Actualidad \& Divulgación Científica 2014; 17(1): 115-121.

García Y, Bonilla M, Padilla G, Ares AE. Ecología, silvicultura $y$ conservación de los pinares de la región occidental de Cuba (Pinus caribaea var. caribaea y Pinus tropicalis Morelet). Alicante: Publicaciones Universidad de Alicante; 2013.

Hogan KP, Smith AP, Samaniego M. Gas exchange in six tropical semi-deciduous forest canopy tree species during the wet and dry seasons. Biotropica 1995; 27(3): 324-333. 10.2307/2388918

Ingwers MW, Urban J, McGuire MA, Bhuiyan RA, Teskey RO. Physiological attributes of three- and four-needle fascicles of loblolly pine (Pinus taeda L.). Trees 2016; 30: 1923-1933. 10.1007/s00468-016-1421-6

Kimball S, Funk JL, Sandquist DR, Ehleringer JR. Ecophysiological considerations for restoration. In: Kimball S, Funk JL, Sandquist DR, Ehleringer JR, editors. Foundations of restoration ecology. Washington, DC: Island Press; 2016. p. 153-181. 10.5822/978-1-61091-698-1_6

Koussoroplis AM, Pincebourde S, Wacker A. Understanding and predicting physiological performance of organisms in fluctuating and multifactorial environments. Ecological Monographs 2017; 87(2): 178-197. 10.1002/ecm.1247

Pelegrín EG, Vallejo VR, Rubio E, Domenech RT, Miranda EC, Carmona AV et al. El papel de la ecofisiología en la restauración forestal de ecosistemas mediterráneos. Investigación Agraria: Sistemas y Recursos Forestales 2005; 14(3): 446-461.

Pérez del Valle L, Geada López G, Armas Armas I, Piloto Casado JA. Variación anatómica de acículas de Pinus caribaea var. caribaea Barrett y Golfari en seis localidades de Pinar del Río. Revista Forestal Baracoa 2016; 35: 1-8.

Perez-Martin A, Michelazzo C, Torres-Ruiz JM, Flexas J, Fernández, JE, Sebastiani L et al. Regulation of photosynthesis and stomatal and mesophyll conductance under water stress and recovery in olive trees: correlation with gene expression of carbonic anhydrase and aquaporins. Journal of Experimental Botany 2014; 65(12): 31433156. 10.1093/jxb/eru160

Prado CDA, Moraes JAV. Photosynthetic capacity and specific leaf mass in twenty woody species of Cerrado vegetation under field conditions. Photosynthetica 1997; 33(1): 103-112. 10.1023/A:1022183423630

Riikonen J, Kettunen N, Gritsevich M, Hakala T, Särkkä L, Tahvonen R. Growth and development of Norway spruce and Scots pine seedlings under different light spectra. Environmental and Experimental Botany 2016; 121: 112-120. 10.1016/j.envexpbot.2015.06.006

Saibo NJ, Lourenço T, Oliveira MM. Transcription factors and regulation of photosynthetic and related metabolism under environmental stresses. Annals of Botany 2009; 103(4): 609-623. $10.1093 / \mathrm{aob} / \mathrm{mcn} 227$

Singh S, Nangoy RC. Method and apparatus for fast gas exchange, fast gas switching, and programmable gas delivery. United States patent US 9305810. 2016. 
Taiz L, Zeiger E. Fisiología vegetal. Los Angeles: Universidad de California; 2006. v. 2.

Tezara W, Coronel I, Hererra A, Dzib G, Canul-Puc K, CalvoIrabién LM et al. Photosynthetic capacity and terpene production in populations of Lippia graveolens (Mexican oregano) growing wild and in a common garden in the Yucatán peninsula. Industrial Crops and Products 2014; 57: 1-9. 10.1016/j.indcrop.2014.03.012

Tezara W, Fernández MD, Donoso C, Herrera A. Seasonal changes in photosynthesis and stomatal conductance of five plant species from a semiarid ecosystem. Photosynthetica 1998; 35(3): 399-410. 10.1023/A:1006916419260

Tezara W, Martínez D, Rengifo E, Herrera ANA. Photosynthetic responses of the tropical spiny shrub Lycium nodosum (Solanaceae) to drought, soil salinity and saline spray. Annals of Botany 2003; 92(6): 757-765. 10.1093/aob/mcg199

Torngern P, Oren R, Oishi AC, Uebelherr JM, Palmroth S, Tarvainen $\mathrm{L}$ et al. Ecophysiological variation of transpiration of pine forests: synthesis of new and published results. Ecological Applications 2017; 27: 118-133. 10.1002/eap.1423

Vallejo VR, Cortina J, Vilagrosa A, Seva JP, Alloza JA. Problemas y perspectivas de la utilizacion de lenosas autoctonas en la restauracion forestal. In: Rey-Benayas JM, Espigares T, Nicolau JM, editors. Restauracion de ecosistemas mediterraneos. Madrid: Universidad de Alcalá; 2003. p. 11-42.

Vilagrosa AJ, Cortina E, Rubio R, Trubat E, Chirino E, Pelegrín EG et al. El papel de la edcofisiología en la restauración forestal de ecosistemas mediterráneos. Investigación Agraria: Sistemas y Recursos Forestales 2005; 14(3): 446-461.

Warren JM, Iversen CM, Garten CT Jr, Norby RJ, Childs J, Brice D et al. Timing and magnitude of $\mathrm{C}$ partitioning through a young loblolly pine (Pinus taeda L.) stand using ${ }^{13} \mathrm{C}$ labeling and shade treatments. Tree Physiology 2011; 32(6): 799-813. 10.1093/treephys/tpr129

Yang Y, Li C. Photosynthesis and growth adaptation of Pterocarya stenoptera and Pinus elliottii seedlings to submergence and drought. Photosynthetica 2016; 54(1): 120-129. 10.1007/s11099-015-0171-9 